\begin{abstract}
ISSN 1980 - 6477
Journal homepage: www.abms.org.br/site/paginas

Ligia Maria Maraschi da Silva Piletti ${ }^{(1)}(\bowtie)$, Luiz Carlos Ferreira de Souza ${ }^{(1)}$, Mateus Luiz Secretti ${ }^{(3)}$ Marcio Roberto Rigotte ${ }^{(1)}$, Izidro dos Santos de Lima Júnior ${ }^{(1)}$ and Antonio Luiz Viegas Neto(1)

${ }^{11}$ Instituto Federal do Mato Grosso do Sul - IFMS campus Ponta Porã.

E-mail: ligia.piletti@ifms.edu.br marcio.rigotte@ifms.edu.br, izidro.lima@ifms.edu.br, antonio.viegas@ifms.edu.br

\section{AGRONOMIC PERFORMANCE OF SUMMER MAIZE IN CROP ROTATION SYSTEMS}

Abstract - Maize grown in the summer can be an important option for crop rotation with soybean. The objective of this work was to study the agronomic performance of maize in different crop rotation systems. The experiment was conducted at the Experimental Farm belonging to the College of Agricultural Sciences of the Federal University of Grande Dourados (UFGD), located in the municipality of Dourados, MS, in the agricultural year of 2014/15. Randomized block design was used, with ten treatments and four replications. The treatments consisted of precedent crops: white oat (Avena sativa), forage radish (Raphanus sativus L. var. oleifera), showy rattlebox (Crotalaria spectabilis), fodder vetch (Vicia villosa), crambe (Crambe abyssinica), safflower (Carthamus tinctorius L.), niger (Guizothia abyssinica), canola (Brassica napus L. var. oleifera), wheat (Triticum aestivum L.) and fallow. These crops were planted in the fall/winter season of each agricultural year, while maize was sown in October of each year. Plant height, ear insertion height, ear length and diameter, grains per ear, thousand grain weight and yield were evaluated. There was significant difference only for yield, which presented the highest values in the rotation with safflower, canola, forage radish, wheat, white oat and niger.
\end{abstract}

${ }^{2)}$ Universidade Federal da Grande Dourados Email: luizsouza@ufgd.edu.br

Centro Universitário da Grande Dourados E-mail: mateussecretti@hotmail.com

Corresponding author

How to cite

PILETTI, L. M. M. S.;SOUZA, L. C. F.; SECRETTI M. L.; RIGOTTE, M. R.; LIMA JÚNIOR, I. S. VIEGAS NETO, A. L. Agronomic performance of summer maize in crop rotation systems. Revista Brasileira de Milho e Sorgo, v. 19, e1125, 2020
Keywords: Zea mays, oleaginous crops, production systems.

\section{DESEMPENHO AGRONÔMICO DO MILHO VERÃO EM SISTEMAS DE ROTAÇÃO DE CULTURAS}

Resumo - O milho cultivado no verão pode ser uma importante opção para rotação de cultura com a soja. Este trabalho objetivou estudar o desempenho agronômico de milho em diferentes sistemas de rotação de culturas. O experimento foi conduzido na Fazenda Experimental da Faculdade de Ciências Agrárias da UFGD, Dourados, MS, no ano agrícola 2014/15, utilizando o delineamento em blocos casualizados com dez tratamentos e quatro repetições. Os tratamentos foram compostos por culturas antecessoras: aveia branca (Avena sativa), nabo forrageiro (Raphanus sativus L. var. oleiferus), crotalária (Crotalaria spectabilis), ervilhaca (Vicia villosa), crambe (Crambe abyssinica), cártamo (Carthamus tinctorius L.), níger (Guizothia abyssinica), canola (Brassica napus L. var. oleifera), trigo (Triticum aestivum L.) e pousio. Elas foram semeadas no outono-inverno de cada ano agrícola e o milho foi semeado em outubro de cada ano. Foram avaliados: altura de planta, altura de inserção de espiga, comprimento e diâmetro de espiga, grãos por espiga, massa de mil grãos e produtividade. Houve diferença significativa apenas para a produtividade e as maiores produtividades foram obtidas na rotação com cártamo, canola, nabo forrageiro, trigo, aveia branca e níger.

Palavras-chave: Zea mays, culturas oleaginosas, sistemas de produção. 
In the state of Mato Grosso do Sul, in the 2018/19 crop season, the area used for soybean cultivation was 2.8 million hectares and for maize (summer) 16 thousand hectares. In the second crop season, the area for maize cultivation was 1.6 million hectares. Due to economic reasons, the farmers prefer producing maize in the second crop season instead of the cultivation in the first season (Conab, 2020).

In the summer, the average maize yield in the state of Mato Grosso do Sul is higher than in the second crop season. According to data provided by Conab (2020), in the summer of $2018 / 2019$, maize production was $8,200 \mathrm{~kg}$ $\mathrm{ha}^{-1}$, on average, while in the second season of the same agricultural year, the production was $5,040 \mathrm{~kg} \mathrm{ha}^{-1}$. Considering the way that the crop distribution is characterized in the agricultural areas, it is evidenced that most of the grain producers use no-tillage system, with no soil preparation. However, in most of the areas, there are no crop rotations, with the soybean-maize succession always being used.

Crop rotations, together with permanent cover and no soil disturbance, constitute the basic principles of the no-tillage system (NTS). Non-utilization of this practice results in the occurrence of chemical, physical and biological alterations in the soil, which may compromise the stability of the production system. Andrade et al. (2009), when studying different cover crops in NTS, observed larger average diameter of aggregates on the soil where different crops were grown in rotation system. The same authors also observed lower soil bulk density and higher values of total porosity with the increase of organic matter.

In addition to the benefits to soil physical properties, the straw decomposition also benefits its chemical structure. Crusciol et al. (2008) concluded that, in black oat crop, nutrients like $\mathrm{N}, \mathrm{P}, \mathrm{Ca}$ and $\mathrm{S}$ are gradually released throughout the straw decomposition period, while there is a faster release of $\mathrm{K}$ right after straw management. The forage radish, another cover crop option, presents quick dry mass degradation in the preflowering stage, releasing substantial amounts of macronutrients (Crusciol et al., 2008).

An important characteristic that shall be taken into consideration when selecting plant species to compose rotation systems is the $\mathrm{C} / \mathrm{N}$ ratio. According to Moreira and Siqueira (2002), in the presence of phytomass with high $\mathrm{N}$ concentration and, consequently, low $\mathrm{C} / \mathrm{N}$ ratio, such as legume species in general, the microorganisms' demand for $\mathrm{N}$ in the decomposition process is satisfied rapidly, and the $\mathrm{N}$ in excess starts to be released to the soil. On the other hand, if the $\mathrm{N}$ concentration of plant residues is low (high $\mathrm{C} / \mathrm{N}$ ratio), the amount of mineralized $\mathrm{N}$ is not sufficient to meet the microorganisms' demand and they start to immobilize mineral $\mathrm{N}$ available in the soil, which usually happens with grasses in general. However, plants with high $\mathrm{C} / \mathrm{N}$ ratio present slower decomposition and promote greater soil cover over time when compared with plants with lower C/N ratio (Perin et al., 2004). 
The main advantages of crop rotation are: contribution to improvement and maintenance of soil fertility; lower incidence of pests, diseases and weeds in the crop; greater crop diversification in the property, which reduces the risks of failure in the agricultural activity; and maintenance and improvement of crop yield (Fidelis et al., 2003). Even with the several benefits promoted by crop rotations being known, this practice is still employed by few farmers. Thus, a change in the way of thinking about the agricultural activity is necessary, based on a socio-economic context with environmental concerns (Mancin et al., 2009).

Maize is important in the composition of crop rotation systems, both in summer crop and second crop season. The yield average of the country is $5,719 \mathrm{~kg} \mathrm{ha}^{-1}$, much lower than its physiological potential (Conab, 2020). Crop rotation using maize is an opportunity for the use of oleaginous plant species in fall/winter, which may produce good benefit-cost ratios, in addition to enhancing the productive performance of the precedent crops (Lourenção, 2012).

In the state of Mato Grosso do Sul, some works were developed with maize grown in the summer as part of rotation systems, with high maize yields being highlighted in these systems. Souza et al. (2016), when assessing different rotation systems and different fall /winter crops preceding summer maize, observed yield of 9,196 $\mathrm{kg} \mathrm{ha}^{-1}$ when maize was grown after niger crop. High yields were also found by Freitas (2014) when assessing different rotation systems in the 2010/11 crop season in the south of Mato Grosso do Sul. He verified maize yield of $11,923 \mathrm{~kg} \mathrm{ha-1}$, which is a much higher yield when compared with the state average $(6,700 \mathrm{~kg}$ $\left.\mathrm{ha}^{-1}\right)$.

Maize is regarded as an important crop to be used in the summer season, with great yield potential, which, besides allowing the rotation with soybean, also enables options of fall/winter plant species to be included in these systems. In this context, the objective of this work was to study the effects of different crop rotation systems on the agronomic performance of maize.

\section{Material and Methods}

The experiment was developed at the Agricultural Sciences Experimental Farm of the Federal University of Grande Dourados (UFGD), located in the municipality of Dourados, with the following geographic coordinates: $22^{\circ} 14^{\prime} \mathrm{S}$ latitude, 54 ${ }^{\circ}$ 49' $\mathrm{W}$ longitude, and $458 \mathrm{~m}$ altitude. According to the Koppen classification, the climate is Am (tropical monsoon). The total annual precipitation in the region is 1,400 to 1,500 $\mathrm{mm}$ and the average annual temperature is $22{ }^{\circ} \mathrm{C}$. The predominant soil in the experimental area is the dystroferric Red Latosol (Santos et al., 2006), with clayey texture. The chemical analysis of the soil, based on sampling carried out in September 2013, is presented in Table 1. The location where the experiment was developed has been under no-tillage system (NTS) since 2009, when limestone and gypsum were applied, according 


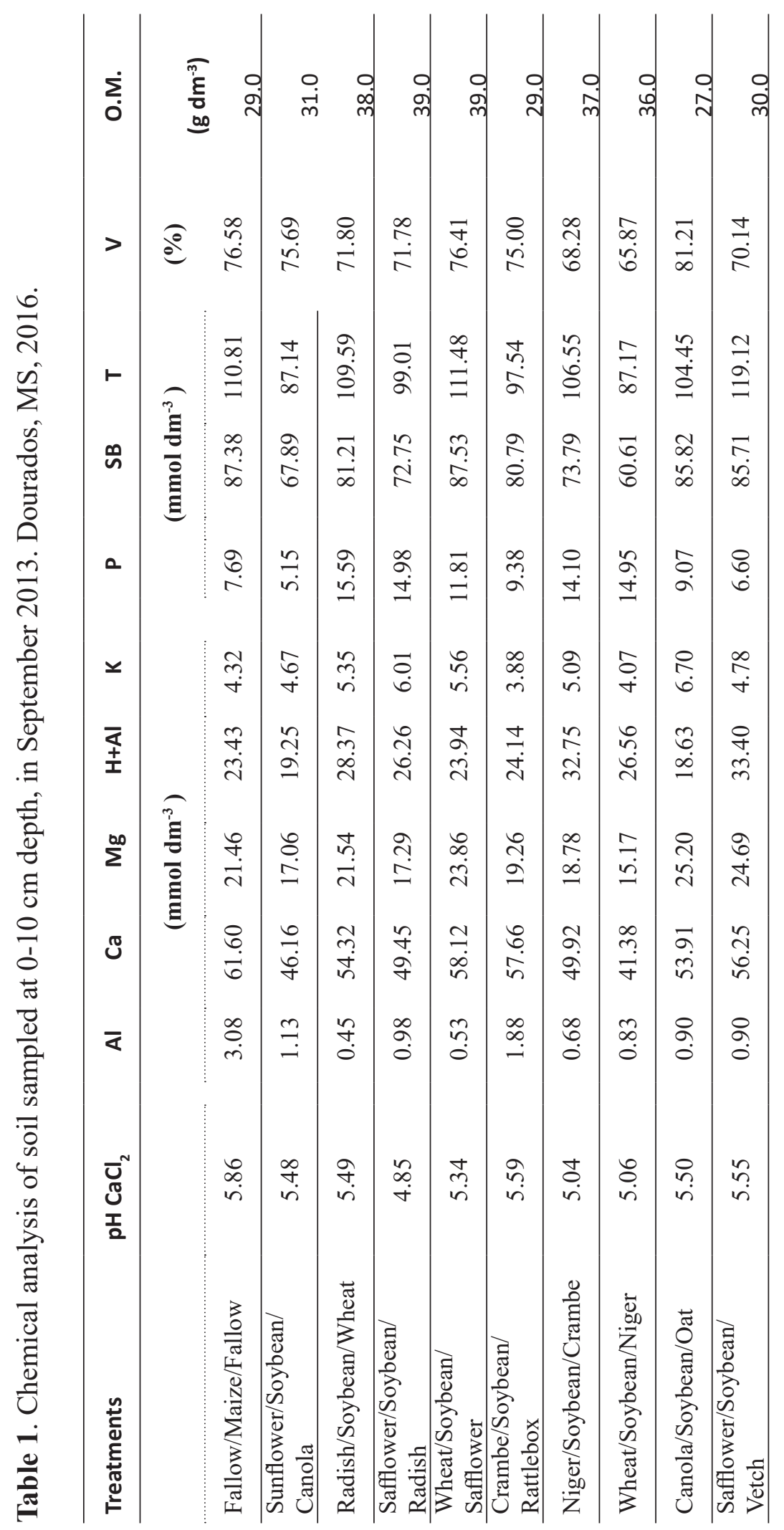


to requirements indicated on that occasion by soil analysis.

Randomized block design was used, with ten treatments (Table 2) and four replications. Each experimental unit was $35 \mathrm{~m}$ long x $15 \mathrm{~m}$ wide, totaling an area of $525 \mathrm{~m}^{2}$.

The 2014/15 crop season was evaluated, with treatments being established in the fall/winter period and consisting of crop rotations with: oleaginous species - canola (Brassica napus L. var. oleifera), safflower (Carthamus tinctorius L.), crambe (Crambe abyssinica), and niger (Guizothia abyssinica); grains - wheat (Triticum aestivum L.) and white oat (Avena sativa); green manure - showy rattlebox (Crotalaria spectabilis), fodder vetch (Vicia villosa), and forage radish (Raphanus sativus L. var. oleifera). In the summer, there was rotation with soybean and maize. One experimental unit was left fallow in the fall/winter, with maize planted in the summer.
Figure 1 shows the data for precipitation and temperature during the first and second crop season periods of the experiment, in the agricultural year of 2014/15.

The treatments consisted of the precedent crops established in the fall/winter periods of each agricultural year, following recommendations for sowing and conducting according to each species. In the fallow treatment, no sowing was done in the fall/winter and weeds were controlled as required.

Showy rattlebox, niger, forage radish (IPR 116), wheat (BRS 210), oat, fodder vetch, canola (Hyola 61), crambe (Brilhante FMS) and safflower were sown in the beginning of April 2014. A planter was used for sowing of the fall/winter crops, being equipped with eight row units, spaced $0.4 \mathrm{~m}$ apart, and regulated to distribute using $200 \mathrm{~kg} \mathrm{ha}^{-1}$ of fertilizer (07-20$20+0.3 \mathrm{~B}+0.3 \mathrm{Zn})$. The planting density was

Table 2. Sequence of treatments for the experiment carried out in the 2014/15 crop season. Dourados, MS, 2016.

Winter 2013/Summer 2014/Winter 2014

Summer 2014/15

Vetch/Soybean/Oat

Sunflower/Soybean/Canola

Radish/Soybean/Safflower

Rattlebox/Soybean/Crambe

Oat/Soybean/Vetch

Wheat/Fallow/Radish

Crambe/Soybean/Niger

Fallow/Soybean/Fallow

Niger/Soybean/Rattlebox

Safflower/Soybean/Wheat
Maize

Maize

Maize

Maize

Maize

Maize

Maize

Maize

Maize

Maize 

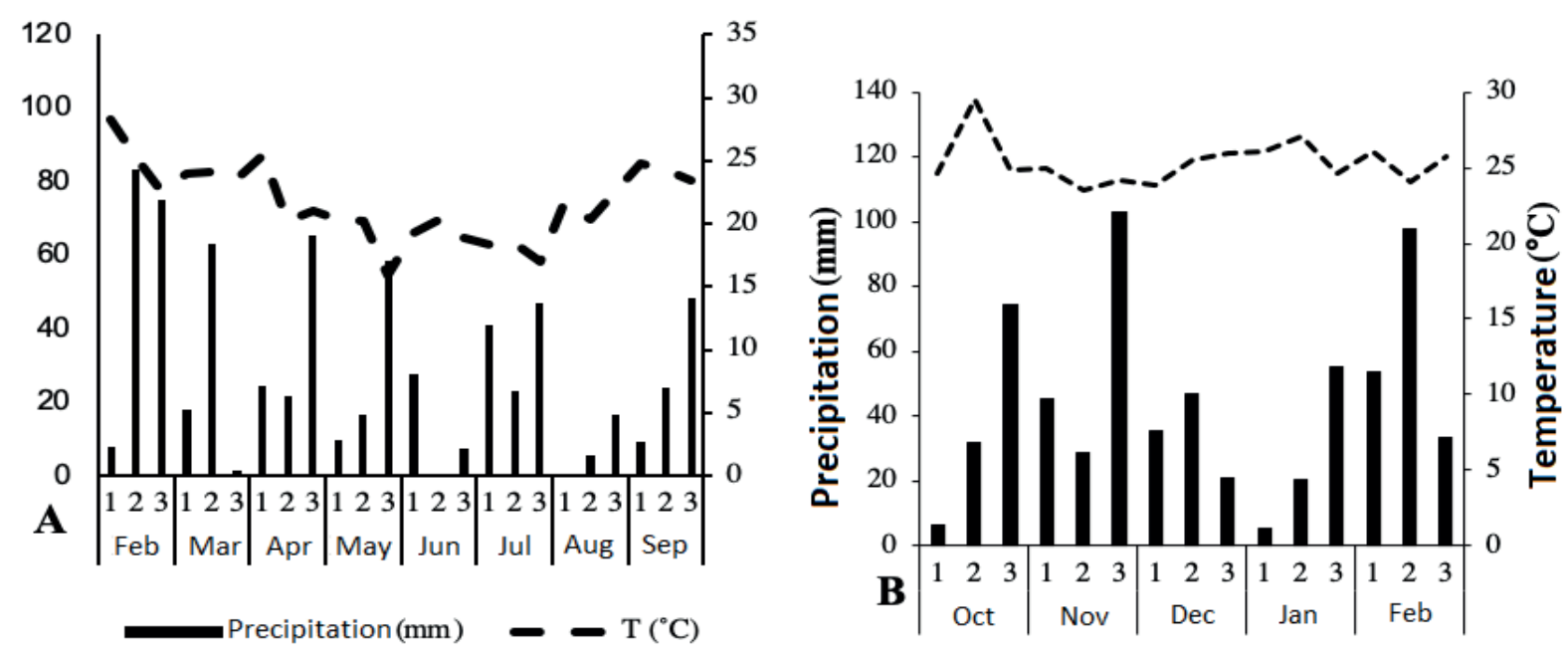

Precipitation $(\mathrm{mm})$

-- $-\mathrm{T}\left({ }^{\circ} \mathrm{C}\right)$

Figure 1. Precipitation and temperature per 10-day period, from February to September 2014 (A) and from October 2014 to February 2015 (B). Source: Embrapa weather station. Dourados, MS, 2016.

60 seeds $\mathrm{m}^{-1}$ for wheat and oat, and 25 seeds $\mathrm{m}^{-1}$ for the other crops.

The fall/winter crops were harvested at the end of each species' cycle and, after the mechanical harvesting of grains, two straw samples were randomly collected within each plot, with the use of an iron frame measuring $0.5 \mathrm{~m} \times 0.5 \mathrm{~m}$, which corresponded to $0.25 \mathrm{~m}^{2}$. The straw was dried in a forced air circulation oven at a temperature of $60^{\circ} \mathrm{C}$. Subsequently, the straw was ground and submitted to chemical analysis for determination of $\mathrm{N}$ contents, following the procedures described by Bataglia et al. (1983). $\mathrm{C}$ was determined through the method described by Tedesco et al. (1985). These data were then used to calculate the $\mathrm{C} / \mathrm{N}$ ratio for the materials deposited on the soil.

The DKB 390 VT PRO, an early single- cross hybrid, was used in the summer maize sowing done on 10/22/2014. A pneumatic planter was used, equipped with seven row units, spaced $0.9 \mathrm{~m}$ apart. At sowing, $300 \mathrm{Kg} \mathrm{ha}^{-1}$ of the 07-20$20+0.3 \% \mathrm{~B}+0.3 \% \mathrm{Zn}$ formulation was applied. Topdressing was applied when the maize plants were in the V4 stage (Ritchie et al., 1993), with $60 \mathrm{~kg} \mathrm{ha}^{-1}$ of $\mathrm{N}$, using urea as the nitrogen source. Weed control was carried out with the application of $0.7 \mathrm{~L} \mathrm{ha}^{-1}$ of nicosulfuron to control broad- and narrow-leaved weeds, and $3.0 \mathrm{~L} \mathrm{ha}^{-1}$ of atrazine to control broad-leaved weeds. The control of the fall armyworm (Spodoptera frugiperda) was done with two spraying operations with insecticides whose active ingredient was flubendiamide, in the dose of $70 \mathrm{~mL} \mathrm{ha-1}$ c.p., and beta-cyfluthrin + imidacloprid, in the dose of $500 \mathrm{~mL} \mathrm{ha}^{-1}$ c.p. The first spraying was done with flubendiamide 
in the V6 stage (Ritchie et al., 1993) and the second spraying was done with beta-cyfluthrin + imidacloprid, when the plants were in the V8 stage.

Maize harvesting was done in February 2014, when two rows of $5 \mathrm{~m}$ were manually harvested, being randomly sampled within each plot. By the time of harvesting, the following maize crop components were determined: plant height, ear insertion height, ear diameter and length, number of grains per ear, grain yield, and thousand grain weight.

Data relative to all assessed variables were submitted to analysis of variance in order to verify the effects of the treatments, with the means being compared by Scott-Knott test at 5\% probability.

\section{Results and Discussion}

The analysis of variance indicated that there was no significant difference among the treatments as to plant height and ear insertion height, with values that are in accordance with those described for this hybrid, which was expected since it is a single-cross hybrid with high homogeneity among the plants (Table 3).

According to Li et al. (2007), plant height and ear insertion height are quantitative attributes of great relevance and are directly related to the tolerance to lodging, since they decrease the center of gravity of the maize plant.

It was also observed that there was no significant difference for ear length, ear diameter, grains per ear (Table 4), and thousand grain weight (Table 5). In the same area of the experiment, in the 2013/14 crop season, Souza et al. (2016) found significant difference among the treatments applied, with the safflower, crambe, niger, oat and vetch presenting higher values for ear diameter and grains per ear.

Ohland et al. (2005) affirm that ear length, ear diameter, number of ears per area and density of grains are characteristics that, together with the genotype, determine the yield potential of the crop.

Grain mass is a characteristic that is influenced by the genotype, availability of nutrients and climate conditions during the grain filling stage (Ohland et al., 2005).

Significant difference was observed in regard to grain yield, with higher values found for maize grown in succession to safflower, canola, forage radish, wheat, oat and niger, thus differing from the other treatments (Table 5). Souza et al. (2016) verified greater maize yields in the same experimental area, in the 2013/14 crop season, when the previous crops were niger, oat, fodder vetch, crambe, showy rattlebox and safflower. Franchini (2014) observed maize yield of $5,989.75 \mathrm{~kg} \mathrm{ha}^{-1}$ after safflower, with this yield being considered intermediate in his experiment.

A research developed by Franchini (2014) demonstrated that the summer maize crop presented one of the greatest yields of the experiment $\left(6,468 \mathrm{~kg} \mathrm{ha}^{-1}\right)$ when grown in succession to canola. That yield was statistically identical to those provided by niger and forage 
Table 3. Plant height and ear insertion height of maize submitted to different previous crops. Dourados, MS, 2016.

\begin{tabular}{lcc}
\hline Previous crops & Plant height $(\mathbf{m})$ & Ear insertion height(m) \\
\hline Vetch/Soybean/Oat & $2.27^{\mathrm{ns}}$ & $1.23^{\mathrm{ns}}$ \\
Sunflower/Soybean/Canola & 2.36 & 1.28 \\
Radish/Soybean/Safflower & 2.34 & 1.29 \\
Rattlebox/Soybean/Crambe & 2.38 & 1.35 \\
Oat/Soybean/Vetch & 2.29 & 1.33 \\
Wheat/Fallow/Radish & 2.36 & 1.32 \\
Crambe/Soybean/Niger & 2.33 & 1.35 \\
Fallow/Soybean/Fallow & 2.42 & 1.35 \\
Niger/Soybean/Rattlebox & 2.40 & 1.36 \\
Safflower/Soybean/Wheat & 2.41 & 1.43 \\
\hline CV (\%) & 3.00 & 4.50 \\
ns: do not statistically differ as per F-test $(\mathrm{p}<0.05)$. &
\end{tabular}

Table 4. Ear length, ear diameter and grains per ear of maize submitted to different previous crops. Dourados, MS, 2016.

\begin{tabular}{|c|c|c|c|c|}
\hline Previous crops & Ear length & $(\mathrm{cm})$ & Ear diameter (cm) & Grains per ear (un) \\
\hline Vetch/Soybean/Oat & $19.8^{\text {ns }}$ & & $4.6^{\mathrm{ns}}$ & $497.5^{\text {ns }}$ \\
\hline Sunflower/Soybean/Canola & 21.3 & & 4.6 & 538.9 \\
\hline Radish/Soybean/Safflower & 21.2 & & 4.7 & 530.2 \\
\hline Rattlebox/Soybean/Crambe & 19.1 & & 4.7 & 449.3 \\
\hline Oat/Soybean/Vetch & 19.5 & & 4.5 & 433.3 \\
\hline Wheat/Fallow/Radish & 20.2 & & 4.7 & 503.8 \\
\hline Crambe/Soybean/Niger & 19.5 & & 4.7 & 489.3 \\
\hline Fallow/Soybean/Fallow & 20.2 & & 4.5 & 489.1 \\
\hline Niger/Soybean/Rattlebox & 19.9 & & 4.5 & 459.1 \\
\hline Safflower/Soybean/Wheat & 20.6 & & 4.8 & 488.2 \\
\hline CV $(\%)$ & 6.30 & & 3.00 & 9.50 \\
\hline
\end{tabular}


Table 5. Average grain yield of maize in different crop rotation systems. Dourados, MS, 2016.

\begin{tabular}{|c|c|c|}
\hline Rotation system & $\begin{array}{c}1000 \text { grain weight } \\
(\mathrm{g})\end{array}$ & $\begin{array}{c}\text { Yield } \\
\left(\mathrm{kg} \mathrm{ha}^{-1}\right)\end{array}$ \\
\hline Vetch/Soybean/Oat & $376.1^{\mathrm{ns}}$ & $8,509 \mathrm{a}^{1}$ \\
\hline Sunflower/Soybean/Canola & 355.3 & $9,490 \mathrm{a}$ \\
\hline Radish/Soybean/Safflower & 388.3 & $9,826 \mathrm{a}$ \\
\hline Rattlebox/Soybean/Crambe & 336.6 & $7,856 \mathrm{~b}$ \\
\hline Oat/Soybean/Vetch & 400.7 & $7,930 \mathrm{~b}$ \\
\hline Wheat/Fallow/Radish & 370.8 & $8,936 \mathrm{a}$ \\
\hline Crambe/Soybean/Niger & 369.4 & $8,401 \mathrm{a}$ \\
\hline Fallow/Soybean/Fallow & 349.5 & $7,362 \mathrm{~b}$ \\
\hline Niger/Soybean/Rattlebox & 352.1 & $8,056 \mathrm{~b}$ \\
\hline Safflower/Soybean/Wheat & 366.3 & $8,895 \mathrm{a}$ \\
\hline CV (\%) & 6.80 & 9.59 \\
\hline
\end{tabular}

${ }^{1}$ Means followed by the same letter do not significantly differ as per Scott Knott test at $5 \%$ probability.

radish. Freitas (2014) also observed higher maize yield of 9,169 $\mathrm{kg} \mathrm{ha}^{-1}$ after canola.

Although the canola has provided high maize yield in the 2014/15 crop season, its straw production was smaller in relation to the other treatments (Table 6) and inferior to the straw production deemed suitable for NTS. According to Alvarenga et al. (2001), straw values above $6,000 \mathrm{~kg} \mathrm{ha}^{-1}$ of dry phytomass are appropriate for soil cover in no-tillage system.

Forage radish was among the precedent crops that provided greater yield $\left(8,936 \mathrm{~kg} \mathrm{ha}^{-1}\right)$ to the maize crop (Table 5). The radish is regarded as an important crop to be included in rotation systems due to its excellent nutrient cycling. This crop promoted good soil cover (6.26 $\mathrm{Mg} \mathrm{ha}^{-1}$ ), with values deemed suitable for maize sowing establishment in NTS. Such results corroborate Franchini (2014) and Souza et al. (2016) who found one of the highest yields for maize grown after forage radish, in their respective experiments, when compared with other crops in rotation with maize.

Wheat was in the group of crops that promoted higher maize yields $\left(8,895 \mathrm{~kg} \mathrm{ha}^{-1}\right)$. Freitas (2014) also found greater yield for maize grown after wheat $\left(9,145 \mathrm{~kg} \mathrm{ha}^{-1}\right)$ in the $2010 / 11$ crop season; while no statistical difference was observed for maize yield in 2011/12, after rotation systems involving wheat, fallow, niger, safflower, crambe, forage radish and sunflower. In the 2013/14 crop season, Souza et al. (2016) observed that the wheat was among the crops that provided lower maize yields.

Maize grown in succession to oat presented yield above $8,500 \mathrm{~kg} \mathrm{ha}^{-1}$, which is considered satisfactory (Table 5). Oat was also one of the crops that provided larger straw supply to the system (Table 6). Menezes (2016), when studying the yield of maize in succession 
Table 6. Straw production $\left(\mathrm{Mg} \mathrm{ha}^{-1}\right)$ and $\mathrm{C} / \mathrm{N}$ ratio of fall/winter crops in 2014. Dourados, MS, 2016.

\begin{tabular}{ccc}
\hline Crop & Straw & C/N ratio \\
\hline Niger & $4.49 \mathrm{~b}$ & 20.0 \\
Canola & $2.66 \mathrm{c}$ & 20.0 \\
Vetch & $4.30 \mathrm{~b}$ & 13.5 \\
Radish & $6.26 \mathrm{a}$ & 22.0 \\
Crambe & $4.86 \mathrm{~b}$ & 14.0 \\
Rattlebox & $6.60 \mathrm{a}$ & 13.0 \\
Safflower & $6.20 \mathrm{a}$ & 30.0 \\
Wheat & $4.73 \mathrm{~b}$ & 29.0 \\
Oat & $6.13 \mathrm{a}$ & 32.0 \\
\hline CV (\%) & $\mathbf{1 3 . 4 5}$ & \\
\hline
\end{tabular}

*Means followed by different letters in the column differ as per F-test $(\mathrm{p}<0.05)$.

to black oat in Paraná, found value of $11,930 \mathrm{~kg}$ ha ${ }^{-1}$ when nitrogen fertilizer was applied to the maize crop, though with lower yield $(5,360 \mathrm{~kg}$ $\mathrm{ha}^{-1}$ ) when nitrogen fertilizer was not used. In 2013/14, Souza et al. (2016) also reported that the oat promoted one of the highest yields for the maize planted in succession.

Maize grown after niger presented yield of $8,401 \mathrm{~kg} \mathrm{ha}^{-1}$, thus not differing significantly from safflower, canola, radish, wheat and oat. In their study, Souza et al. (2016) concluded that niger is recommended for rotation systems preceding maize crop, which presented the highest yield, followed by sunflower and crambe.

Although the amount of straw produced by the niger crop was inferior to the production regarded as ideal for NTS, niger presents high rates of extraction of nutrients from the soil (Mauad et al., 2015). These authors concluded that niger plants present low values for export of nutrients and harvest index, which results in greater provision of nutrients for the crop in rotation.

In this experiment, maize planted in succession to fodder vetch presented yield below the state average $\left(7,930 \mathrm{~kg} \mathrm{ha}^{-1}\right)$ in the $2014 / 15$ crop season. The straw production of fodder vetch in 2014 was below the value recommended for full development of the no-tillage system (4.30 $\left.\mathrm{Mg} \mathrm{ha}^{-1}\right)$. One of the factors that favors fodder vetch, when considering its use in crop rotation systems, is its contribution to the supply of nitrogen to the soil. Menezes (2016) found yield of $10.650 \mathrm{~kg} \mathrm{ha}^{-1}$ for maize grown after fodder vetch, even with no application of nitrogen fertilizer.

As antecedent crop, crambe provided yield of $7,856 \mathrm{~kg} \mathrm{ha}^{-1}$, which is considered one of the lowest values found among the treatments (Table 5). Franchini (2014) also verified lower yield $\left(5.970 \mathrm{~kg} \mathrm{ha}^{-1}\right)$ for maize planted in succession to crambe in $2010 / 11$. 
Showy rattlebox produced one of the greatest straw contributions to the system, being higher than what is regarded as ideal $(6 \mathrm{Mg}$ $\mathrm{ha}^{-1}$ ), and maize yield of $8,056 \mathrm{~kg} \mathrm{ha}^{-1}$. High dry phytomass production has been reported for showy rattlebox. Suzuki and Alves (2006) observed production of $9.83 \mathrm{Mg} \mathrm{ha}^{-1}$, while 12.8 $\mathrm{Mg} \mathrm{ha}^{-1}$ was found by Wutke (1993).

The dissimilar behavior of the precedent crops in the different years may be a result of climate conditions in fall/winter, which may benefit one crop but not the other, since they are different species, from different botanical families, and each one of them presents certain conditions that favor its development. The dissimilar behavior also suggests that the rotation combination throughout the years significantly influences the behavior of the plants grown in succession.

It was possible to observe low maize yield of $7,362 \mathrm{~kg} \mathrm{ha}^{-1}$, when the plot was left fallow in the fall/winter period in 2014/15. These results corroborate those found by Franchini (2014), Freitas (2014) and Souza et al. (2016), who verified yields of 5,443 $\mathrm{kg} \mathrm{ha}^{-1}, 6,699 \mathrm{~kg} \mathrm{ha}^{-1}$ and $6,774 \mathrm{~kg} \mathrm{ha}^{-1}$, respectively. Carneiro et al. (2008), when assessing different cover crop species and fallow period, found lower dry matter production in the area left fallow, as well as high population density of weeds such as blackjack (Bidens pilosa L.), sourgrass (Digitaria insularis) and fanpetals/sida (Sida glaziovii K. Schum.), which emphasizes the importance of using plant species as soil cover in the off-season period in fall/ winter.

\section{Conclusions}

Maize grown in succession to white oat, canola, safflower, forage radish, niger and wheat presents higher yields. Oleaginous crops are good options to integrate crop rotation systems with maize in the summer. Forage radish, showy rattlebox, safflower and white oat crops provide straw production suitable for no-tillage system.

\section{Acknowledgments}

To FUNDECT/CAPES for the financial support provided through scholarship; and to UFGD for the support given to the project development.

\section{References}

ALVARENGA, R. C.; CABEZAS, W. A. L.; CRUZ, J. C.; SANTANA, D. P. Plantas de cobertura de solo para sistema plantio direto. Informe Agropecuário, v. 22, p. 25-36, 2001.

ANDRADE, R. S.; STONE, L. F.; SILVEIRA, P. M. Culturas de cobertura e qualidade física de um Latossolo em plantio direto. Revista Brasileira Engenharia Agrícola e Ambiental, v. 13, n. 4, p. 411-418, 2009. DOI: 10.1590/ S1415-43662009000400007.

BATAGLiA, O. C.; FURLANI, A. M. C.; TEIXEIRA, J. P. F.; FURLANI, P. R.; GALLO, J. R. Métodos de análise química de plantas. 
Campinas: Instituto Agronômico, 1983. 48 p. (Boletim Técnico, 78).

CARNEIRO, M. A. C.; CORDEIRO, M. A. S.; ASSIS, P. C. R.; MORAES, E. S.; PEREIRA, H. S.; PAUlinO, H. B.; SOUZA, E. D. Produção de fitomassa de diferentes espécies de cobertura e suas alterações na atividade microbiana de solo de cerrado. Bragantia, v. 67, n. 2, p. 455-462, 2008. DOI: $10.1590 / S 0006-87052008000200021$.

CONAB. Companhia Nacional de Abastecimento. Série histórica das safras. Brasília, DF, 2020. Disponível em: <https://www.conab.gov.br/infoagro/safras/serie-historica-das-safras $>$. Acesso em: 11 jun. 2020.

CRUSCIOL, C. A. C.; MORO, E.; LIMA, E. V.; ANDREOTTI, M. Taxas de decomposição e de liberação de macronutrientes da palhada de aveia preta em plantio direto. Bragantia, v. 67 , n. 2, p. 481-489, 2008. DOI: 10.1590/S000687052008000200024 .

FIDELIS, R. R.; ROCHA, R. N. C.; LEITE, V. T.; TANCREDI, F. D. Alguns aspectos do plantio direto para a cultura da soja. Bioscience Jounal, v. 19, n. 1, p. 23-31, 2003.

FRANCHINI, R. G. Rotação de culturas com oleaginosas e gramíneas na produção de soja e milho. 2014. 99 f. Tese (Doutorado em Produção Vegetal) - Universidade Federal da Grande Dourados, Dourados, MS, 2014.

FREITAS, M. E. Rotação e sucessão de culturas com ênfase em oleaginosas de outono-inverno em plantio direto. 2014. 83 f. Tese (Doutorado em Produção Vegetal) Universidade Federal da Grande Dourados, Dourados, MS, 2014.

LI, Y.; DONG, Y.; NIU, S.; CUI, D. The genetics relationships among plant-height traits found using multiple trait QTL mapping of a dent corn and popcorn cross. Genome, v. 50, n. 4, p. 357-364, 2007. DOI: 10.1139/g07-018.

LOURENÇÃO, A. L. F. Resultados de experimentação e campos demonstrativos de milho safra 2011/2012. In: TECNOLOGIA e produção de soja e milho 2012/2013. Maracajú, MS: Fundação MS, 2012. 228 p.

MANCIN, C.R.; SOUZA, L.C.F.; NOVELINO, J. O.; MARCHETTI, M. E.; GONÇALVES, M. C. Desempenho agronômico da soja sob diferentes rotações e sucessões de culturas em sistema plantio direto. Acta Scientiarum Agronomy, v. 31, n. 1, p. 71-77, 2009. DOI: 10.4025/actasciagron.v31i1.6631.

MAUAD, M.; GARCIA, R. A.; MUSSURY, R. M.; SILVA, T. A. F.; SCHROEDER, I. M.; KNUDSEN, C. H.; QUARESMA, E. V. W. Produção de matéria seca e acúmulo de macronutrientes na parte aérea das plantas de niger. Revista Brasileira de Ciência 
do Solo, v. 39, n. 2, p. 533-540, 2015. DOI: 10.1590/01000683rbcs20140391.

MENEZES, C. R. J. Adubação nitrogenada no milho em sucessão às plantas de cobertura sob sistemas de cultivo do solo. 2016. 65 f. Dissertação (Mestrado) - Universidade Tecnológica Federal do Paraná, Pato Branco, 2016.

MOREIRA, F. M. S.; SIQUEIRA, J. O. Microbiologia e bioquímica do solo. Lavras: Universidade Federal de Lavras, 2002. 626 p.

OHLAND, R.A.A.; SOUZA, L.C.F.; HERNANI, L. C.; MARCHETTI, M. E.; GONÇALVES, M. C. Culturas de cobertura do solo e adubação nitrogenada no milho em plantio direto. Ciência e Agrotecnologia, v. 29, n. 3, p. 538-544, 2005. DOI: 10.1590/S1413-70542005000300005.

PERIN, A.; SANTOS, R. H. S.; URQUIAGA, S. Produção de fitomassa, acúmulo de nutrientes e fixação biológica de nitrogênio por adubos verdes em cultivo isolado e consorciado. Pesquisa Agropecuária Brasileira, v. 39, n. 1, p. 35-40, 2004. DOI: 10.1590/S0100$204 X 2004000100005$.

RITCHIE, S. W.; HANWAY, J. J.; BENSON, G. O. How a corn plant develops. Ames: Iowa State University of Science and Technology, 1993. 26 p. (Special Report, v. 48).
SANTOS, H. G. dos; JACOMINE, P. K. T.; ANJOS, L. H. C. dos; OLIVEIRA, V. A. de; OlIVEIRA, J. B. de; COELHO, M. R.; LUMBRERAS, J. F.; CUNHA, T. J. F. (Ed.). Sistema brasileiro de classificação de solos. 2 . ed. Rio de Janeiro: Embrapa Solos, 2006. 306 p.

SOUZA, L. C. F.; LUIZ, A. J.; PILETTI, L. M. M. S. Características agronômicas do milho em função da cultura antecessora em sistema plantio direto. Revista Brasileira de Milho e Sorgo, v. 15, n. 2, p. 272-280, 2016. DOI: 10.18512/19806477/rbms.v15n2p272-280.

SUZUKI, L. E. A. S.; ALVES, M. C. Fitomassa de plantas de cobertura em diferentes sucessões de culturas e sistemas de cultivo. Bragantia, v. 65, n. 1, p. 121-127, 2006.

DOI: 10.1590/S0006-87052006000100016.

TEDESCO, M. J.; VOLKWEISS, S. J.; BOHNEN, H. Análise de solo, plantas e outros materiais. Porto Alegre: Universidade Federal do Rio Grande do Sul, 1985. 188 p. (Boletim Técnico de Solos, 5).

WUTKE, E. B. Adubação verde: manejo da fitomassa e espécies utilizadas no Estado de São Paulo. In: WUTKE, E. B.; BULISANI, E. A.; MASCARENHAS, H. A. A. (Coord.). Curso sobre adubação verde no Instituto Agronômico. Campinas: IAC, 1993. p. 17-29. (Documentos IAC, 35). 